\title{
A MECHANISTIC STUDY ON THE REACTIONS OF VINYL CARBENE WITH HYDROGEN, CARBON MONOXIDE AND CARBON DIOXIDE: SHED LIGHT ON FURTHER MANIPULATIONS
}

\author{
Cem Burak YILDIZ \\ Department of Medicinal and Aromatic Plants, University of Aksaray, 68100, Aksaray, Turkey
}

\begin{abstract}
Density Functional calculations have been used to explore the potential energy profiles of $\mathrm{H}_{2}, \mathrm{CO}$, and $\mathrm{CO}_{2}$ activation reactions by vinyl carbene structure 1 . The reactions of vinyl carbene 1 with $\mathrm{CO}_{2}$ was proposed to yield a variety of possible products (3-5) depending on its selectivity. The density functional calculations established that the proposed reactions of $\mathbf{1}$ with $\mathrm{CO}_{2}$ proceed in a concerted or stepwise manners to form $\mathbf{3}$ and $\mathbf{5}$. However, that of $\mathrm{CO}$ reaction occur in only concerted fashion for the proposed products $\mathbf{1 5}$ and $\mathbf{1 6}$. Furthermore, the compound $\mathbf{1}$ is found to be most reactive than $\mathbf{5}$ and $\mathbf{1 6}$ towards $\mathrm{H}_{2}$ with the required lower energy barrier. Finally, the more dominant routes are determined to be formation processes of $\mathbf{3 , 4}$, and 10.
\end{abstract}

Keywords: Vinyl carbene, Small molecule activation, DFT, $\mathrm{CO}, \mathrm{CO}_{2}$

\section{VINILL KARBEN YAPISININ HIDROJEN, KARBON MONOKSITT VE KARBON DİOKSIT ILLE TEPKIMMELERI ÜZERINE MEKANISTIK BİR ÇALIŞMA: ILLERİ ÇALIŞMALARA BİR IŞIK}

\begin{abstract}
ÖZET
Yoğunluk fonksiyoneli teorisi $\mathrm{H}_{2}, \mathrm{CO}$ ve $\mathrm{CO}_{2}$ moleküllerinin vinil karben $\mathbf{1}$ bileşiği ile aktivasyonu sonucu oluşan enerji yüzeylerini incelemek için kullanılmıştır. Seçiciliğe bağlı olarak vinil karben 1 bileşiğinin $\mathrm{CO}_{2}$ molekülü ile tepkimesi çeşitli muhtemel ürünlerin (3-5) oluşabileceğini önermektedir. Yoğunluk fonksiyoneli teorisi hesaplamaları $\mathbf{3}$ ve $\mathbf{5}$ numaralı ürünlerin oluşum tepkimelerinin tek basamak veya basamak basamak mekanizmalar üzerinden yürüyebileceğini göstermektedir. Buna karşın, 1 numaralı yapının CO ile tepkimesi sonucunda olası ürünler 15 ve 16 yalnızca tek basmak içermektedir. Dahası, $\mathrm{H}_{2}$ aktivasyon tepkimeleri değerlendirildiğinde 1 numaralı yapının 5 ve 16 numaralı yapılara nazaran daha reaktif olduğu elde edilen enerji bariyerleri ile tespit edilmiştir. Sonuç olarak, en uygun mekanizmalar $\mathbf{3 , 4}$ ve $\mathbf{1 0}$ numaralı yapıların oluşumları için tespit edilmiştir.
\end{abstract}

Anahtar Kelimeler: Vinil karben, Küçük molekül aktivasyonu, DFT, $\mathrm{CO}, \mathrm{CO}_{2}$

\section{INTRODUCTION}

Alkylidene carbenes, alkenylidenes, have been known as highly reactive intermediates in organic chemistry [1-5]. Several methods have been improved to generate these highly reactive intermediates [6-13]. In the past few decades, the alkenylidenes have attracted considerable attention due to their role in many organic reactions. They play obvious roles in many organic synthesis with high levels of selectivity [14-25]. Furthermore, the cycloaddition of unsaturated carbenes can provide the synthesis of small ring, highly strained compounds by conventional ways. The 3-dimensional selectivity of substitute groups from the addition reactions of alkylidene carbene to olefins was exemplified in a collaboration of Apeloig and Fox [26,27]. As it can be seen from the literature, there are many reports and discussions on theoretical studies of alkylidene carbenes [28-32]. However, no scientific study has been reported on the activation of small molecules by alkylidene carbenes so far. 
In the present computational study, we would like to distil a general message for the behavior of heavier vinyl carbenes towards hydrogen $\left(\mathrm{H}_{2}\right)$, carbon monoxide $(\mathrm{CO})$, and carbon dioxide $\left(\mathrm{CO}_{2}\right)$. With this incentive, we started by calculations of the energy profiles for the oxidative addition reactions of the considered small molecules with vinyl carbene $\mathbf{1}$ on the basis of proposed mechanisms: The reactions may proceed in either concerted or stepwise fashion to yield variety of different possible products. As we show here, the ketene $+\mathrm{CO}$ complex $\mathbf{4}$ and a kind of cyclic carbene $\mathbf{5}$ can be generated from the proposed reaction of $\mathbf{1}$ with $\mathrm{CO}_{2}$. Although formation process of $\mathbf{4}$ is determined to be exergonic, that of constitutional isomer $\mathbf{5}$ has an endergonic nature with nonspontaneous character. On the other hand, the proposed reaction of $\mathbf{1}$ with $\mathrm{CO}$ depict that the formation of proposed products $\mathbf{1 7}$ and $\mathbf{1 8}$ are strongly endergonic at the level of theories used herein. Furthermore, the $\mathrm{H}_{2}$ activation by $\mathbf{1}$ is found to be more favored than $\mathbf{5}$ and $\mathbf{1 8}$ with the lower energy barriers.

\section{COMPUTATIONAL DETAILS}

Initially, all manipulations were performed using the Gaussian 09 suite of programs [33]. In order to optimize the structures on their potential energy surface in gas phase, Becke's three-hybrid method and the exchange functional of Lee, Yang, and Parr (B3LYP) theory was employed with the 6-311++G(d,p) basis set $[34,35]$. Further, the calculations were repeated with full geometry optimizations at newer theory level of WB97XD/6-311++G(d,p) [36]. The stationary points were characterized as minima or transition structures by vibrational frequency calculations, and all relative energies reported here are Gibbs free energies in $\mathrm{kcal} \mathrm{mol}^{-1}$. The intrinsic reaction coordinates (IRC) were also followed to verify the energy profiles connecting each transition state to the correct local minima, by using the secondorder Gonzalez-Schlegel method [37,38]. The computed structures were visualized by using the GaussView 5.0 program [39].

\section{RESULTS and DISCUSSION}

From the theoretical calculations, vinylidene carbene 1 is known to be singlet ground state $\left(\Delta_{\mathrm{S}-\mathrm{T}}=48\right.$ $\mathrm{kcal} \mathrm{mol}^{-1}$ ) [40]. Due to the high singlet-triplet energy separations, we consider only singlet state of $\mathbf{1}$ for oxidative addition of $\mathrm{H}_{2}, \mathrm{CO}$, and $\mathrm{CO}_{2}$. Several conceptually different pathways have been proposed to explain the ability of vinylidene 1 to activate the related small molecules.

The reaction mechanisms of $\mathbf{1}$ with carbon dioxide $\left(\mathrm{CO}_{2}\right)$ was investigated in this part. The reaction can take place via TS1, TS6, and TS7 which lead to diverse products such as $\mathbf{3}, \mathbf{5}$, and $\mathbf{4}$, respectively. The [1+2] addition of $\mathbf{1}$ to $\mathrm{CO}_{2}$ is found to be slightly exergonic to form proposed product $\mathbf{3}$ via TS1 in a concerted manner by $\Delta \mathrm{G}=-2.4 \mathrm{kcal} \mathrm{mol}^{-1}$ and $-5.6 \mathrm{kcal} \mathrm{mol}^{-1}$ at the B3LYP/6-311++G(d,p) and WB97XD/6-311++G(d,p) level of theories, respectively (Table 1 and Figure 1, black arrows). Then, the intramolecular rearrangement of $\mathbf{3}$ can be considered to form another possible products of $\mathbf{4}$ (ketene + $\mathrm{CO}$ ) by the required energy barrier of $\Delta \mathrm{G}^{\neq}=+5.9 \mathrm{kcal} \mathrm{mol}^{-1}$, so that the overall pathway for 4 starting from 1 is decidedly exergonic by $\Delta \mathrm{G}=-36.1 \mathrm{kcal} \mathrm{mol}^{-1}$ at the B3LYP/6-311++G(d,p) level of theory (Table 1 and Figure 1, red arrows). Moreover, the calculation at the WB97XD/6-311++G(d,p) level is very similar by $\Delta \mathrm{G}=-35.4 \mathrm{kcal} \mathrm{mol}^{-1}$. Based on the theoretical results, the formation of 4 can also be evaluated with direct attack of 1 to oxygen atom of $\mathrm{CO}_{2}$ via TS7 by the required very high energy barrier of $\Delta \mathrm{G}^{\neq}=+47.5 \mathrm{kcal} \mathrm{mol}^{-1}$, the overall pathway of concerted mechanism is determined to be also strongly exergonic by $\Delta \mathrm{G}=-36.1 \mathrm{kcal} \mathrm{mol}^{-1}$ (Table 1 and Figure 1, blue arrows). Next, we considered how to incorporate the product $\mathbf{5}$ from the reaction of $\mathbf{1}$ with $\mathrm{CO}_{2}$ and intermolecular rearrangement of 4. The [2+2] cycloaddition of $\mathbf{1}$ to $\mathrm{CO}_{2}$ can also yield the product 5 by considerably high energy barrier of $\Delta \mathrm{G}^{\neq}=+47.4 \mathrm{kcal} \mathrm{mol}^{-1}$ (Table 1 and Figure 1, green arrows). In this case, the nature of the proposed reaction for 5 via TS6 is found to be endergonic by $\Delta \mathrm{G}=+18.2 \mathrm{kcal} \mathrm{mol}^{-1}$. The related energy barrier and overall pathway at the WB97XD/6-311++G(d,p) level are determined to be relatively lower by $\Delta \mathrm{G}^{\neq}$ $=+43.6 \mathrm{kcal} \mathrm{mol}^{-1}$ and $\Delta \mathrm{G}=+11.7 \mathrm{kcal} \mathrm{mol}^{-1}$, respectively. Similarly, the formation of 5 is also to be existed endergonic from intermolecular rearrangement of 4 (Table 1 and Figure 1, pink arrows). 
Collectively, the dominant reaction route for the reaction 1 with $\mathrm{CO}_{2}$ is determined to be formation process of 4 via TS1 and TS2 with the observed lower energy barriers. Another interesting point is that inclusion of dispersion by WB97XD, which uses a version of Grimme's D2, leads to negligible differences in terms of the energetics and nature of the proposed pathways. For this reason, the following discussions will be based on the results at the B3LYP/6-311++G(d,p) level of theory.

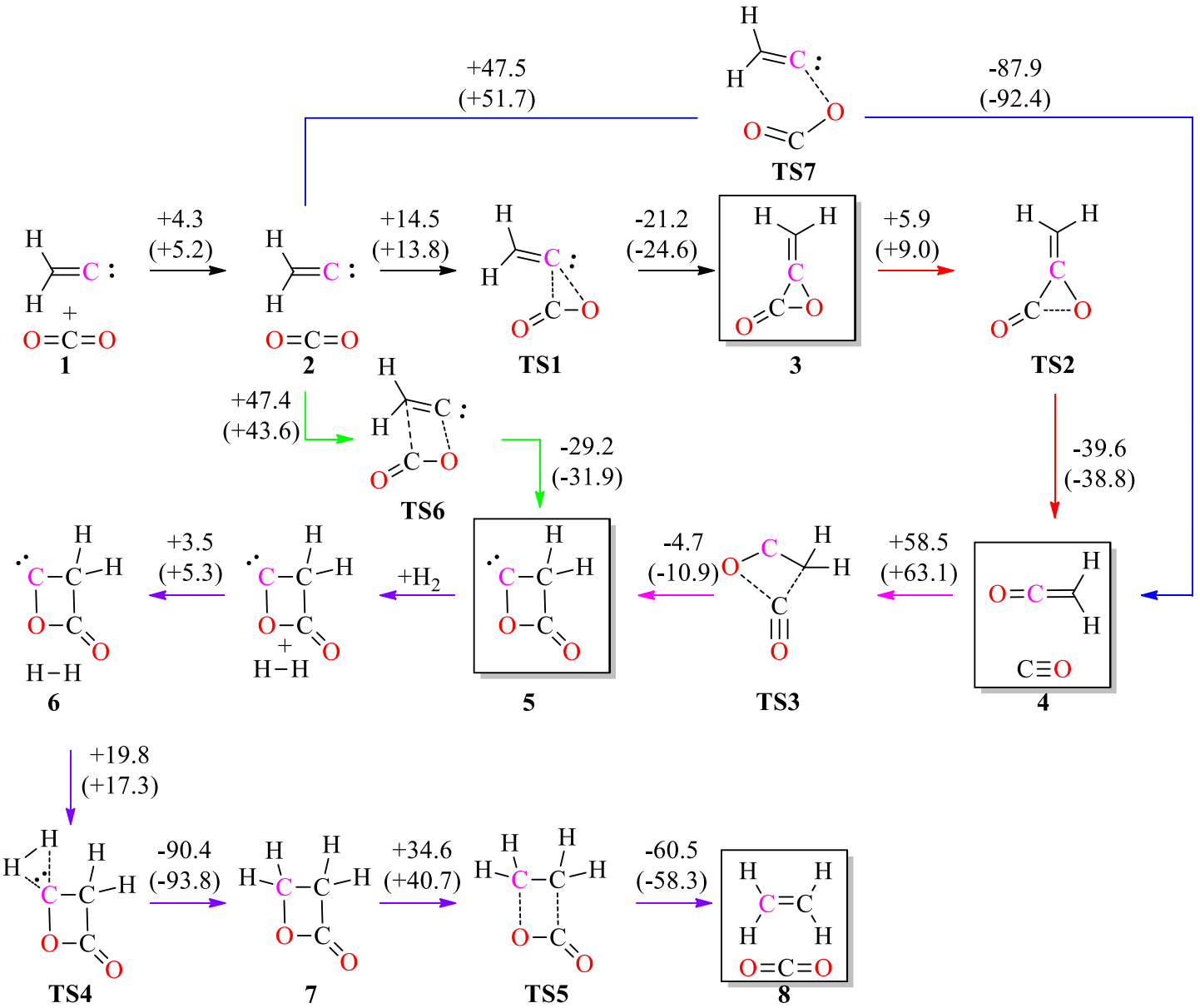

Figure 1. The proposed reaction mechanisms and energy channel for the reaction of vinyl carbene 1 with $\mathrm{CO}_{2}$ and further $\mathrm{H}_{2}$ activation at the B3LYP/6-311++G(d,p) and WB97XD/6$311++\mathrm{G}(\mathrm{d}, \mathrm{p})$ (in parentheses) level of theories $\left(\Delta \mathrm{G}\right.$ energies given in $\left.\mathrm{kcal} \mathrm{mol}^{-1}\right)$

We believe that it is possible to generate $\mathbf{5}$ from $\mathbf{1}+\mathrm{CO}_{2}$ at sufficiently high temperature. In this case, it can be designed the formation of ethylene from the hydrogenation of $\mathbf{5}$. The addition $\mathrm{of}_{2}$ to the resulting product 5 begins with the formation of van der Waals complex $\mathbf{6}$ which is determined to be of higher in energy than the $\mathbf{5}+\mathrm{H}_{2}$ by $\Delta \mathrm{G}=3.5 \mathrm{kcal} \mathrm{mol}^{-1}$. Then, the required energy barrier to form $\mathbf{8}$ is to be existed $\Delta \mathrm{G}^{\neq}=+19.8 \mathrm{kcal} \mathrm{mol}^{-1}$ with strongly exergonic nature. The DFT calculations indicate that the liberation of $\mathrm{CO}_{2}$ from the optimized structure 7 leads to the formation of $\mathbf{8}$ (ethylene $+\mathrm{CO}_{2}$ ) by the considerably high energy barrier of $\Delta \mathrm{G}^{\neq}=+34.6 \mathrm{kcal} \mathrm{mol}^{-1}$, so that the overall pathway for 8 starting from 6 is decidedly exergonic by $\Delta \mathrm{G}=-96.5 \mathrm{kcal} \mathrm{mol}^{-1}$ (Figure 1, purple arrows). 
Table 1. Calculated energy channel for the activation of $\mathrm{CO}_{2}$ and $\mathrm{H}_{2}$ by $\mathbf{1}$ and $\mathbf{5}$ at the B3LYP/6-311++G(d,p) and WB97XD/6-311++G(d,p) (in parentheses) level of theories $\left(\Delta \mathrm{G}\right.$ energies given in $\left.\mathrm{kcal} \mathrm{mol}^{-1}\right)$

\begin{tabular}{|c|c|c|c|}
\hline $\mathrm{CO}_{2}$ activation by 1 & Energy Channel & $\mathrm{H}_{2}$ Activation by 5 & Energy Channel \\
\hline $1 \rightarrow 2$ & $+4.3(+5.2)$ & $5 \rightarrow 6$ & $+3.5(+5.3)$ \\
\hline $2 \rightarrow \mathrm{TS} 1$ & $+14.5(+13.8)$ & $6 \rightarrow \mathrm{TS} 4$ & $+19.8(+17.3)$ \\
\hline TS1 $\rightarrow 3$ & $-21.2(-24.6)$ & TS4 $\rightarrow 7$ & $-90.4(-93.8)$ \\
\hline $3 \rightarrow \mathrm{TS} 2$ & $+5.9(+9.0)$ & $7 \rightarrow$ TS5 & $+34.6(+40.7)$ \\
\hline $\mathrm{TS} 2 \rightarrow 4$ & $-39.6(-38.8)$ & TS5 $\rightarrow 8$ & $-60.5(-58.3)$ \\
\hline $4 \rightarrow \mathrm{TS3}$ & $+58.5(63.1)$ & & \\
\hline TS3 $\rightarrow 5$ & $-4.7(-10.9)$ & & \\
\hline $2 \rightarrow$ TS6 & $+47.4(+43.6)$ & & \\
\hline TS6 $\rightarrow 5$ & $-29.2(-31.9)$ & & \\
\hline $2 \rightarrow \mathrm{TS} 7$ & $+47.5(+51.7)$ & & \\
\hline TS7 $\rightarrow 4$ & $-87.9(-92.4)$ & & \\
\hline
\end{tabular}

Additionally, the activation of $\mathrm{H}_{2}$ by $\mathbf{1}$ is also considered in the presented theoretical study. The modelled mechanism for the direct addition of $\mathrm{H}_{2}$ to $\mathbf{1}$ occurs in a concerted manner to yield ethylene $\mathbf{1 0}$ by the relatively lower energy barrier of $\Delta \mathrm{G}^{\neq}=+12.6 \mathrm{kcal} \mathrm{mol}^{-1}$ as compared to that of 5 (Table 2 and Figure 2, black arrows). Overall, the reaction is determined to be strongly exergonic by $\Delta \mathrm{G}=-79.0 \mathrm{kcal} \mathrm{mol}^{-1}$. The activation of $\mathrm{H}_{2}$ by 1 to generate an ethylene molecule is found to be slightly favorable than that of 5 with the lower energy barrier although the exergonic character of the pathway for $\mathbf{5}+\mathrm{H}_{2}$ is stronger. Furthermore, the mechanistic scenario for the activations of $\mathrm{CO}$ and $\mathrm{CO}_{2}$ by ethylene molecule 10 were examined. As it can be seen from Figure 2, all the proposed mechanisms were determined to be strongly endergonic, showing that the reactions are nonspontaneous and not favorable (Table 2 and Figure 2, red, blue, and green arrows).

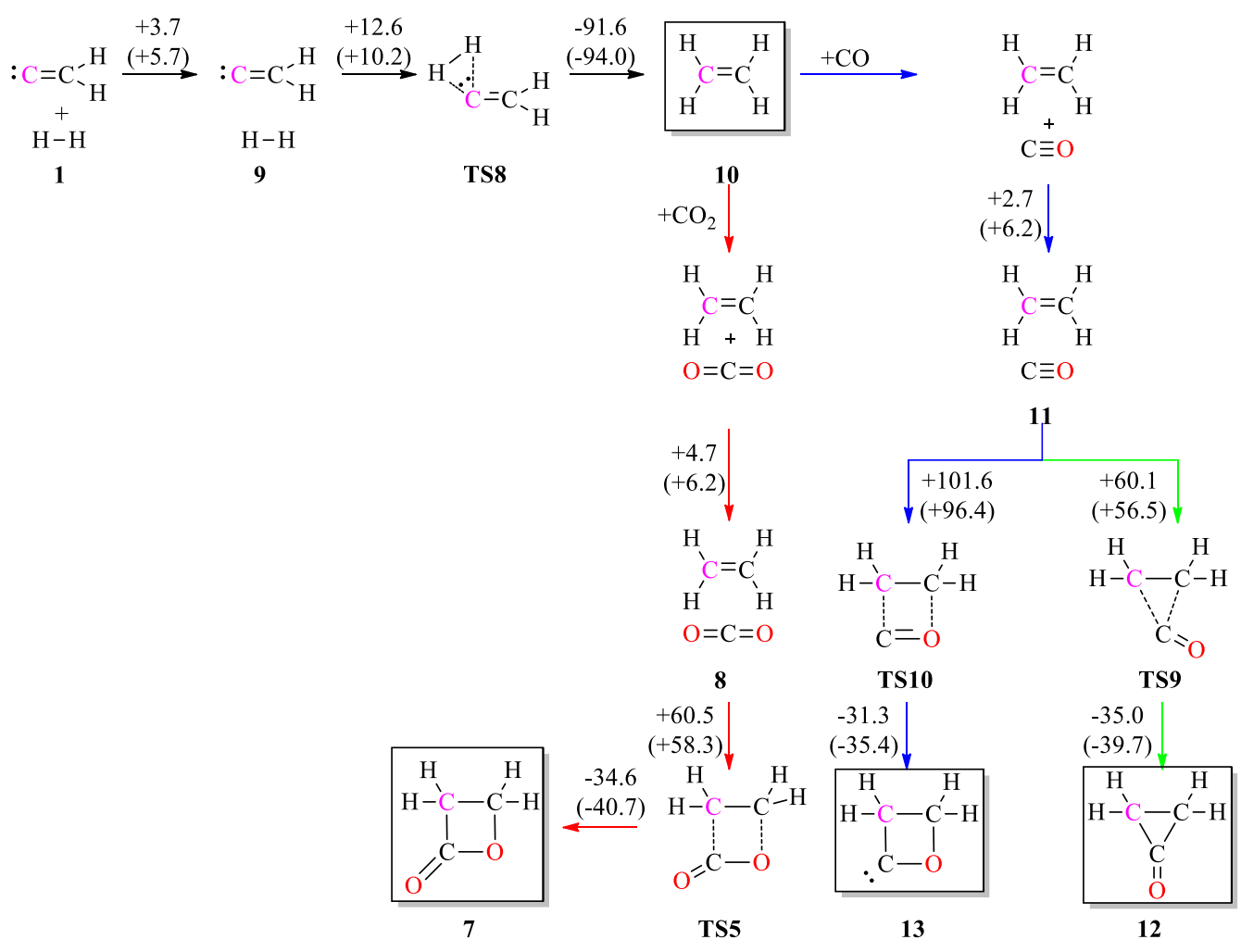

Figure 2. The proposed reaction mechanism for the reaction of vinyl carbene 1 with $\mathrm{H}_{2}$ and further $\mathrm{CO}$ and $\mathrm{CO}_{2}$ activations at the $\mathrm{B} 3 \mathrm{LYP} / 6-311++\mathrm{G}(\mathrm{d}, \mathrm{p})$ and $\mathrm{WB} 97 \mathrm{XD} / 6-311++\mathrm{G}(\mathrm{d}, \mathrm{p})$ (in parentheses) level of theories ( $\Delta \mathrm{G}$ energies given in $\mathrm{kcal} \mathrm{mol}^{-1}$ ) 
Table 2. Calculated energy channel for the activation of $\mathrm{H}_{2}, \mathrm{CO}$, and $\mathrm{CO}_{2}$ by $\mathbf{1}$ and $\mathbf{1 0}$ at the B3LYP/6-311++G(d,p) and WB97XD/6-311++G(d,p) (in parentheses) level of theories $\left(\Delta \mathrm{G}\right.$ energies given in $\mathrm{kcal} \mathrm{mol}^{-1}$ )

\begin{tabular}{cccc}
\hline $\mathrm{H}_{2}$ activation by $\mathbf{1}$ & Energy Channel & $\mathrm{CO}$ and $\mathrm{CO}_{2}$ Activation by $\mathbf{1 0}$ & Energy Channel \\
\hline $\mathbf{1 \rightarrow \mathbf { 9 }}$ & $+3.7(+5.7)$ & $\mathbf{1 0} \rightarrow \mathbf{8}$ & $+4.7(+6.2)$ \\
$\mathbf{9} \rightarrow \mathbf{T S 8}$ & $+12.6(+10.2)$ & $\mathbf{8} \rightarrow \mathbf{T S 5}$ & $+60.5(+58.3)$ \\
$\mathbf{T S 8} \rightarrow \mathbf{1 0}$ & $-91.6(-94.0)$ & $\mathbf{T S 5} \rightarrow \mathbf{7}$ & $-34.6(-40.7)$ \\
& & $\mathbf{1 0} \rightarrow \mathbf{1 1}$ & $+2.7(+6.2)$ \\
& & $\mathbf{1 1 \rightarrow} \mathbf{T S 9}$ & $+60.1(+56.5)$ \\
& $\mathbf{T S 9} \rightarrow \mathbf{1 2}$ & $-35.0(-39.7)$ \\
& $\mathbf{1 1 \rightarrow T S 1 0}$ & $+101.6(+96.4)$ \\
& & $\mathbf{T S 1 0} \rightarrow \mathbf{1 3}$ & $-31.3(-35.4)$ \\
\hline
\end{tabular}

In order to test the possibility of the CO activation by vinyl carbene 1, the DFT calculations were carried out for the modelled system. Two competitive concerted pathways can be considered from intermolecular rearrangement of $\mathbf{1}$ and $\mathrm{CO}$ to form the possible products of $\mathbf{1 5}$ and $\mathbf{1 6}$. In accordance with the activation mechanism of $\mathrm{CO}_{2}$, the $\mathrm{CO}$ included trends follow almost same order to form related proposed products with [1+2] and [2+2] cycloaddition steps via TS11 and TS12, respectively. Although the possible [1+2] addition step of $\mathbf{1}$ to $\mathrm{CO}_{2}$ for $\mathbf{3}$ needs lower energy barrier with exergonic nature, the overall pathway for $\mathbf{1 5}$ is determined to be strongly endergonic by $\Delta \mathrm{G}=17.1 \mathrm{kcal} \mathrm{mol}^{-1}$ in the case of $\mathrm{CO}$, indicating that the reaction cannot occur spontaneously (Table 3 and Figure 3, black arrows). Based on the theoretical results, the formation of $\mathbf{1 6}$ is also plausible from the reaction of $\mathbf{1}$ with CO. For this reason, the formation mechanism of $\mathbf{1 6}$ was also designed. By this way, we can reach a dicarbene compound 16. However, the calculations show that the formation of $\mathbf{1 6}$ is strongly endergonic and the required energy barrier is too high for a reaction at room temperature (Table 3 and Figure 3, blue arrows).

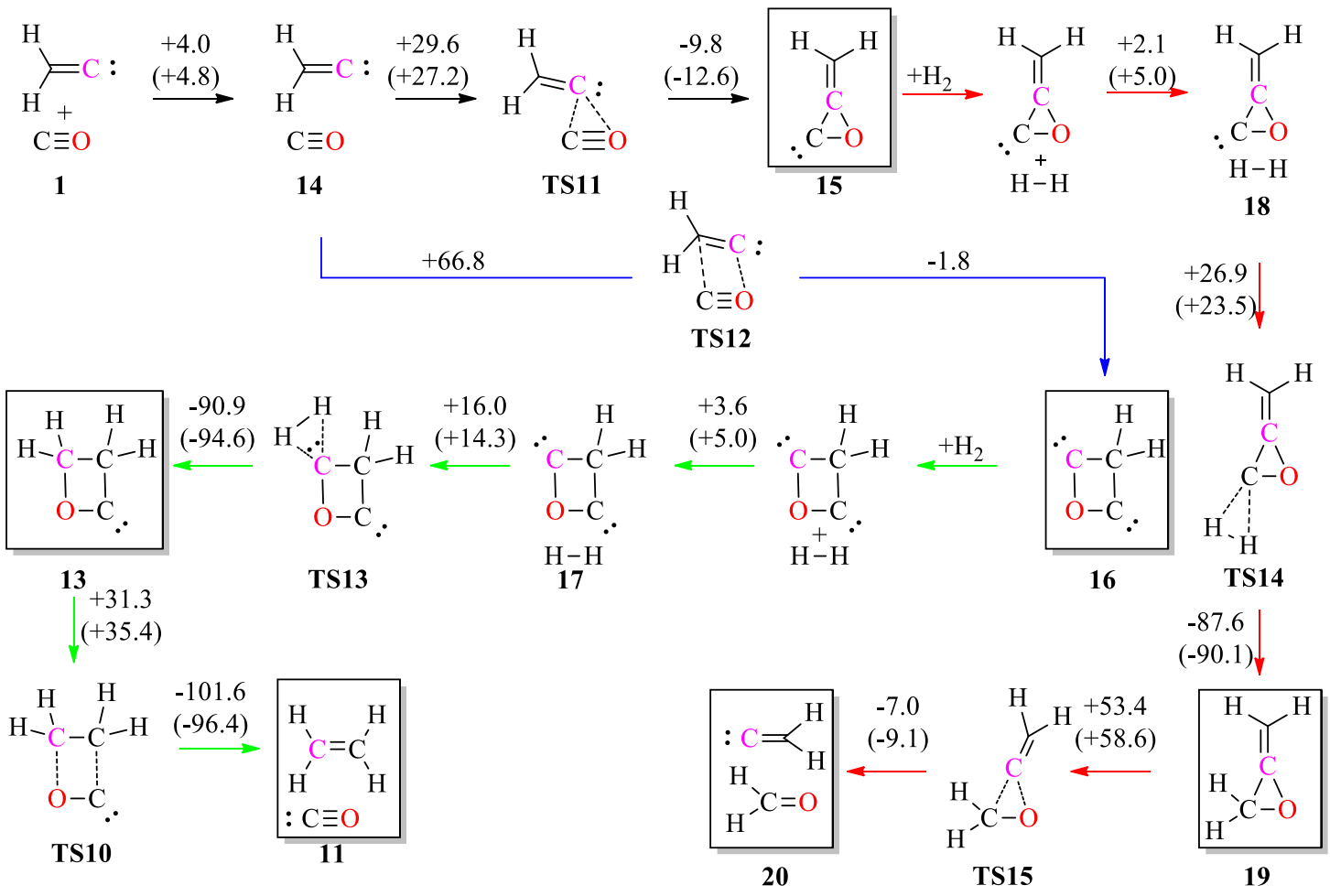

Figure 3. The proposed reaction mechanisms for the reaction of vinyl carbene 1 with $\mathrm{CO}$ and further $\mathrm{H}_{2}$ activation at the B3LYP/6-311++G(d,p) and WB97XD/6-311++G(d,p) (in parentheses) level of theories $\left(\Delta \mathrm{G}\right.$ energies given in $\left.\mathrm{kcal} \mathrm{mol}^{-1}\right)$. 
In case of any possible synthesis of $\mathbf{1 5}$ and $\mathbf{1 6}$ at sufficiently high temperature, we also designed their $\mathrm{H}_{2}$ activation mechanisms to generate $\mathbf{1 1}$ (ethylene $+\mathrm{CO}$ ) and $\mathbf{2 0}$ (Vinylidene carbene + formaldehyde). The direct addition of $\mathrm{H}_{2}$ to the proposed product $\mathbf{1 5}$ can form the related van der Waals complex of $\mathbf{1 8}$ which is more stable than $\mathbf{1 5}+\mathrm{H}_{2}$ by $\Delta \mathrm{G}=-2.1 \mathrm{kcal} \mathrm{mol}^{-1}$ (Table 3 and Figure 3 , red arrows). Clearly, the hydrogenation of the $\mathbf{1 5}$ can proceed by direct addition of $\mathrm{H}_{2}$ to the carbenic center of 15 via TS14. This process requires $26.9 \mathrm{kcal} \mathrm{mol}^{-1}$ energy barrier to overcome for the formation of 19 . Then, the decomposition of 19 to form 20 can be activated with the cleavage of $\mathrm{C}-\mathrm{C}$ and $\mathrm{C}-\mathrm{O}$ bonds in a concerted manner by the very high energy barrier of $\Delta \mathrm{G}^{\neq}=+53.4 \mathrm{kcal} \mathrm{mol}^{-1}$ (Table 3 and Figure 3 , red arrows). Separately, the calculations indicate that the addition of $\mathrm{H}_{2}$ can be feasibly binded to the one of the carbenic centers in 16, forming possible compound $\mathbf{1 3}$ by the required relatively lower energy barrier of $\Delta \mathrm{G}^{\neq}=+16.0 \mathrm{kcal} \mathrm{mol}^{-1}$ (Table 3 and Figure 3, green arrows). We found that the formation processes of $\mathbf{1 3}$ from the van der Waals complex of $\mathbf{1 7}$ is strongly exergonic by $\Delta \mathrm{G}=-74.9 \mathrm{kcal} \mathrm{mol}^{-1}$. Additionally, the subsequent $\mathrm{CO}$ elimination from the structure $\mathbf{1 3}$ was also investigated. In the following rearrangement, it is possible to yield the ethylene $+\mathrm{CO}$ mixture 11 via the transition state of TS10 and the process is exergonic by $\Delta \mathrm{G}=-70.5 \mathrm{kcal} \mathrm{mol}^{-1}$. (Figure 3). Overall, the reaction starting from 17 is determined to be strongly exergonic by $\Delta \mathrm{G}=-145.4 \mathrm{kcal} \mathrm{mol}^{-1}$.

Table 3. Calculated energy channel for the activation of $\mathrm{CO}$ and $\mathrm{H}_{2}$ by $\mathbf{1}, \mathbf{1 5}$ and $\mathbf{1 6}$ at the B3LYP/6-311++G(d,p) and WB97XD/6-311++G(d,p) (in parentheses) level of theories $\left(\Delta \mathrm{G}\right.$ energies given in $\left.\mathrm{kcal} \mathrm{mol}^{-1}\right)$.

\begin{tabular}{cccc}
\hline CO activation by $\mathbf{1}$ & Energy Channel & $\mathrm{H}_{2}$ Activation by $\mathbf{1 5}$ and $\mathbf{1 6}$ & Energy Channel \\
\hline $\mathbf{1} \rightarrow \mathbf{1 4}$ & $+4.0(+4.8)$ & $\mathbf{1 5} \rightarrow \mathbf{1 8}$ & $+2.1(+5.0)$ \\
$\mathbf{1 4} \rightarrow \mathbf{T S 1 1}$ & $+29.6(27.2)$ & $\mathbf{1 8} \rightarrow \mathbf{T S 1 4}$ & $+26.9(+23.5)$ \\
$\mathbf{T S 1 1} \rightarrow \mathbf{1 5}$ & $-9.8(-12.6)$ & $\mathbf{T S 1 4} \rightarrow \mathbf{1 9}$ & $-87.6(-90.1)$ \\
$\mathbf{1 4} \rightarrow \mathbf{T S 1 2}$ & $+66.8(+62.4)$ & $\mathbf{1 9 \rightarrow} \rightarrow \mathbf{T S 1 5}$ & $+53.4(+58.6)$ \\
$\mathbf{T S 1 2} \rightarrow \mathbf{1 6}$ & $-1.8(-2.7)$ & $\mathbf{T S 1 5} \rightarrow \mathbf{2 0}$ & $-7.0(-9.1)$ \\
& & $\mathbf{1 6} \rightarrow \mathbf{1 7}$ & $+3.6(+5.0)$ \\
& & $\mathbf{1 7} \rightarrow \mathbf{T S 1 3}$ & $+16.0(+14.3)$ \\
& TS13 $\rightarrow \mathbf{1 3}$ & $-90.9(-94.6)$ \\
& $\mathbf{1 3 \rightarrow T S 1 1 0}$ & $+31.3(+35.4)$ \\
& & $\mathbf{T S 1 0} \rightarrow \mathbf{1 1}$ & $-101.6(-96.4)$ \\
\hline
\end{tabular}

\section{CONCLUSION}

Using B3LYP theory with 6-311++G(d,p) basis set, the activation reaction mechanism of $\mathrm{H}_{2}, \mathrm{CO}$, and $\mathrm{CO}_{2}$ by $1,5,10,15$, and 16 were studied. The calculations depict that the reactions may proceed in either concerted or stepwise fashion to yield a variety of different possible products. The proposed reactions can occur in concerted and stepwise manners to generate $\mathbf{3}, \mathbf{4}$, or 5 from $\mathbf{1}+\mathrm{CO}_{2}$. The nature of the formation process of $\mathbf{4}$ is strongly exergonic, whereas that of constitutional isomer $\mathbf{5}$ is determined to be endergonic with the proposed mechanisms. Additionally, the activation of $\mathrm{H}_{2}$ by $\mathbf{5}$ was also considered in the presented theoretical study. The computed relative $\Delta \mathrm{G}$ energies indicated that the formation of $\mathbf{8}$ (ethylene $+\mathrm{CO}_{2}$ ) is exergonic with energy of $-96.5 \mathrm{kcal} \mathrm{mol}^{-1}$ at the B3LYP/6-311++G(d,p) level of theory. In the case of $\mathrm{CO}$ activation by $\mathbf{1}$, the proposed reactions is strongly endergonic for both products 15 and 16. In spite of this, however, the required energy for the activation of $\mathrm{H}_{2}$ by $\mathbf{1 6}$ is relatively lower with $\Delta \mathrm{G}^{\neq}=+16.0 \mathrm{kcal} \mathrm{mol}^{-1}$. Overall, the formation process of $\mathbf{1 1}$ starting from $\mathbf{1 7}$ is determined to be strongly exergonic by $\Delta \mathrm{G}=-145.4 \mathrm{kcal} \mathrm{mol}^{-1}$. Collectively, the formation processes of $\mathbf{3 , 4}$, and $\mathbf{1 0}$ are found to be favorable with the obtained facile energy values. 


\section{REFERENCES}

[1] Kirmse W. Carbene Chemistry, 2nd ed. New York, NY, USA: Academic Press, 1971.

[2] Gilchrist T. L. Carbenes and Nitrenes, in Organic Reaction Mechanisms. Chichester, UK: Wiley, 1972.

[3] Wentrup C. Reactive Molecules. New York, NY, USA: Wiley, 1984.

[4] Doyle MP, Forbes DC. Recent advances in asymmetric catalytic metal carbene transformations. Chem Rev. 1998; 98: 911-935.

[5] Richard SG, Kevin RM. Recent advances in alkylidene carbene chemistry. Tetrahedron 2015; 71 : $7795-7835$.

[6] Ohira S, Sawamoto T, Yamato M. Synthesis of (-)-neplanocin A via C-H insertion of alkylidenecarbene. Tetrahedron Lett. 1995; 36: 1537-1538.

[7] Eisler S, Tykwinski RR. Migrating alkynes in vinylidene carbenoids: An unprecedented route to polyynes. J Am Chem Soc. 2000; 122: 10736-10737.

[8] Van Nhien AN, León R, Postel D, Carreiras MC, García AG, Marco-Contelles J.1,6-C-H and 1,5-O$\mathrm{Si}$ insertion reactions of alkylidenecarbene derivatives of monosaccharides. J Carbohyd Chem. 2005; 24; 369-377.

[9] Tsai CC, Chien CT, Chang YC, Lin HC, Yan TH. Intramolecular C-H insertion by an alkylidene carbene: Diastereoselective Synthesis of a Taxol A Ring Synthon. J Org Chem. 2005; 70: 5745-5747.

[10] Satoh T. Recent advances in the chemistry of magnesium carbenoids. Chem Soc Rev. 2007; 36: $1561-1572$.

[11] Satoh T. Recent Advances in the chemistry and synthetic uses of magnesium carbenoids. Heterocycles 2012; 85: 1-33.

[12] Quinodoz P, Wright K, Drouillat B, David O, Marrot J, Couty F. Synthesis of homopropargylamines from 2-cyanoazetidines. Chem Commun. 2016; 52: 10072-10075.

[13] Frihed TG, Bols M, Pedersen CM. C-H Functionalization on carbohydrates. European J Org Chem. 2016; 16: 2740-2756.

[14] Stang PJ. Unsaturated carbenes. Chem Rev 1978; 78: 383-405.

[15] Stang PJ, Fisk TE. Extended unsaturated carbenes. Generation and nature of alkadienylidenecarbenes. J Chem Soc 1980; 102; 6813-6816.

[16] Stang, PJ. Vinyl carbamates via interaction of alkylidenecarbenes with isocyanates. J Organomet Chem. 1981; 46: 4585-4586.

[17] Stang PJ, Bjork JA. Reaction of isopropylidenecarbene with isonitriles. Evidence for the formation of alkadienylideneamine. Chem Commun 1978; 23: 1057-1058. 
[18] Brown RFC, Eastwood FW, Harrington KJ, McMullen GL. Methyleneketenes and methylenecarbenes. Aust J Chem. 1974; 27: 2393-2402.

[19] Feldman KS, Perkins AL. 1,6-C-H insertion of alkylidenecarbenes in 1-naphthol and 1-anthrol derivatives. Tetrahedron Lett. 2001; 42: 6031-6033.

[20] Bonomo L, Stern C, Solari E, Scopelliti R, Floriani C. Acetylenes rearranging on RutheniumPorphyrinogen and leading to vinylidene and carbene functionalities. Angew Chem Int Ed 2001: 40: $1449-1452$.

[21] Ciardi, C.; Reginato, G.; Gonsalvi L, de los Rios I, Romerosa A, Peruzzini M. Ruthenium(II) $\pi$-alkyne and vinylidene complexes derived from glycoynitols: New precursors for water-soluble unsaturated carbenes. Organometallics. 2004; 23: 2020-2026.

[22] Cheng CJ, Tong HC, Fong YH, Wang PY, Kuo YL, Lo YH, Lin CH. Reactions of $\mathrm{Tp}(\mathrm{NH}=\mathrm{CPh} 2)(\mathrm{PPh} 3) \mathrm{Ru}-\mathrm{Cl}$ with $\mathrm{HC} \equiv \mathrm{CPh}$ in the presence of $\mathrm{H} 2 \mathrm{O}$ : insertion/hydration products Dalton Trans. 2009; 4435-4438.

[23] Ma ESF, Patrick BO, James BR. Reactions of phenylacetylene and p-tolylacetylene with a five-coordinate RuII complex. Inorg Chim Acta. 2013; 408: 126-130.

[24] Bucher J, Stoßer T, Rudolph M, Rominger F, Hashmi ASK. CO Extrusion in homogeneous gold catalysis: Reactivity of gold acyl species generated through water addition to gold vinylidenes. Angew Chem Int Ed 2015; 54: 1666-1670.

[25] Raubenheimer HG. Gold acyl complex formation and decarbonylation during indene synthesis from catalytically active vinylidene complexes. ChemCatChem. 2015; 7: 1261-1262.

[26] Apeloig Y, Karni M, Stang PJ, Fox DP. Transition-state geometries and stereoselectivity of alkylidenecarbene addition to olefins. An experimental and theoretical investigation. J Am Chem Soc 1983; 105: 4781-4792.

[27] Fox DP, Stang PJ, Apeloig Y, Karni M. Stereoselectivity of alkylidenecarbene addition to olefins. 2. Effect of orbital polarization in the alkenes. J Am Chem Soc 1986; 108: 750-756.

[28] Lu XH, Wang YX. Theoretical studies on mechanisms of cycloaddition reaction between dichlorovinylidene and formaldehyde: Concerted and Stepwise? J Phys Chem A 2003; 107: 7885-7890.

[29] Lu XH, Wu WR, Yu HB, Yang XL, Xu YH. A theoretical study on the mechanism of cycloaddition reaction between vinylidene and acetone. J Mol Struct (Theochem) 2005; 755: 39-44.

[30] $\mathrm{Lu} \mathrm{XH,} \mathrm{Yu} \mathrm{HB,} \mathrm{Wu} \mathrm{WR,} \mathrm{Xu} \mathrm{YH.} \mathrm{Theoretical} \mathrm{studies} \mathrm{of} \mathrm{mechanisms} \mathrm{of} \mathrm{cycloaddition} \mathrm{reaction}$ between difluoromethylene carbene and acetone. Int J Quantum Chem 2007; 107: 451-457.

[31] Lu XH, Xiang PP, Wu WR, Che X. Theoretical study on mechanism of cycloaddition reaction between dimethyl methylene carbene and ethylene. J Mol Struct (Theochem) 2008; 853: 82-88.

[32] Lu X, Lian Z, Li Y. An ab initio study of the mechanism of the cycloaddition reaction forming bicyclic compounds between vinylidene $(\mathrm{H} 2 \mathrm{C}=\mathrm{C}$ : ) and ethylene. J Serb Chem Soc 2011: 76; 743-749.

[33] Frisch MJ, Trucks GW, Schlegel HB, Scuseria GE, Robb MA, Cheeseman JR, Montgomery Jr JA, Vreven T, Kudin K.N, Burant J.C, Millam J.M, Iyengar SS, Tomasi J, Barone V, Mennucci B, Cossi M, 
Scalmani G, Rega N, Petersson GA, Nakatsuji H, Hada M, Ehara M, Toyota K, Fukuda R, Hasegawa J, Ishida M, Nakajima T, Honda Y, Kitao O, Nakai H, Klene M, Li X, Knox JE, Hratchian HP, Cross JB, Bakken V, Adamo C, Jaramillo J, Gomperts R, Stratmann RE, Yazyev O, Austin AJ, Cammi R, Pomelli C, Ochterski JW, Ayala PY, Morokuma K, Voth GA, P Salvador, Dannenberg JJ, Zakrzewski VG, Dapprich S, Daniels AD, Strain MC, Farkas O, Malick DK, Rabuck AD, Raghavachari K, Foresman JB, Ortiz JV, Cui Q, Baboul AG, Clifford S, Cioslowski J, Stefanov BB, Liu G, Liashenko A, Piskorz P, Komaromi I, Martin RL, Fox DJ, Keith T, Al-Laham MA, Peng CY, Nanayakkara A, Challacombe M, Gill PMW, Johnson B, Chen W, Wong MW, Gonzalez C, Pople JA, Gaussian 03, Revision E.01, Gaussian 09, Inc: Wallingford CT, 2009.

[34] Becke AD. Density-functional thermochemistry. III. The role of exact exchange. J Chem Phys 1993; 98: $5648-5652$.

[35] Lee C, Yang W, Parr RG. Development of the Colle-Salvetti correlation-energy formula into a functional of the electron density. Phys Rev B 1998; 37: 785-789.

[36] Chai JD, Head-Gordon M Long-range corrected hybrid density functionals with damped atomatomdispersion corrections. Phys Chem Chem Phys 2008; 10: 6615-6620.

[37] Gonzalez C, Schlegel HB. Improved algorithms for reaction path following: higher-order implicit algorithms. J Chem Phys 1991; 95: 5853-5860.

[38] Wiberg KB. Application of the pople-santry-segal CNDO method to the cyclopropylcarbinyl and cyclobutyl cation and to bicyclobutane. Tetrahedron 1968; 24: 1083-1096.

[39] Dennington RII, Keith T, Millam J, Eppinnett K, Hovell WL, Gilliland R (2009) GaussView v.5.0.9 Visualizer and Builder. Gaussian 09. Wallingford, CT

[40] Wu CJ, Carter EA. Ab initio thermochemistry for unsaturated C2 hydrocarbons. J Phys Chem 1991; 95: 8352-8363. 